\title{
The Politics of Shaft: Positioning a Popular Cultural Icon in 1971, 2000 and 2019
}

\author{
Magnus Dahlstedt1, Peter Ehrström² \\ ${ }^{1}$ Department of Culture and Society, Linköping University, Norrköping, Sweden \\ ${ }^{2}$ Regional Science, Faculty of Education and Welfare Studies, Åbo Akademi University, Vaasa, Finland \\ Email: magnus.dahlstedt@liu.se, peter.ehrstrom@abo.fi
}

How to cite this paper: Dahlstedt, M., \& Ehrström, P. (2021). The Politics of Shaft: Positioning a Popular Cultural Icon in 1971, 2000 and 2019. Open Journal of Political Science, 11, 419-438.

https://doi.org/10.4236/ojps.2021.113029

Received: May 10, 2021

Accepted: July 4, 2021

Published: July 7, 2021

Copyright ( 2021 by author(s) and Scientific Research Publishing Inc. This work is licensed under the Creative Commons Attribution International License (CC BY 4.0).

http://creativecommons.org/licenses/by/4.0/ (c) (i) Open Access

\begin{abstract}
This article focuses on how popular culture relates to both society and politics, as a barometer of the present. In a sense, popular culture both mirrors and articulates specific ways of understanding society, the present. In this article, we will investigate one specific expression of popular culture, the African American action movie hero Shaft, and how this character appears in different shapes, in different times and contexts. The aim of the article is to examine how the character Shaft appears in three movies, from 1971, 2000 and 2019. This examination draws attention to how three different shapes of Shaft materialise, with different values attributed to the character of Shaft. Specific focus is put on the socio-political expressions of the day and the localities where the movies unfold. The analysis highlights three different versions of Shaft, each formed in accordance with the socio-political expressions of the day and manifesting different specific historical contexts. The first version actively portrays the political struggles carried out in the civil rights era, not least concerning race inequalities. On the contrary, the second version is significantly less actively engaged in the political struggles of the day. However, the movie still reflects class-based injustices in an individualised neoliberal era. The third version, in turn, clearly neglects the current social struggles. By celebrating family values, by neglecting existing inequalities as well as the possibilities of collective actions targeting these inequalities, the movie makes a post-political statement, echoing a long-established myth of the "American dream", with hopes of intergenerational social mobility.
\end{abstract}

\section{Keywords}

Shaft, Politics of Representation, Popular Culture, Positioning, Neoliberalism, Race 


\section{Introduction}

In this article, we will illustrate how popular culture relates to both society and politics, as a barometer of the present. In a sense, popular culture both mirrors and articulates specific ways of understanding society, the present (cf. Dahlstedt \& Vesterberg, 2021). In certain times and places, popular culture is politicized, and thus becomes a driver for socio-political change. However, popular culture may also become a means of depoliticization, making the present order of things appear legitimate and seemingly natural (Eyerman, 1998; Giroux, 2000). Thus, the way in which popular culture in specific times and places relates to politics is a topic of great importance for those interested in further understanding political transformations (Dorzweiler, 2016; Street, Inthorn, \& Scott, 2013).

In this article, we will investigate one specific expression of popular culture, the African American action movie hero Shaft, how this character appears in different shapes, in different times and contexts. The first time the character of Shaft appeared in cinema was in the American movie Shaft, in 1971. Since then, Shaft has emerged in movies produced in different times: at the turn of the millennium and, most recently, in 2019. In each movie, in each time, one and the same character emerges, but positioned quite differently. If we examine each movie more closely, with a specific focus on the ways in which the character Shaft is positioned, we may see that they reflect the politics, the time and place, in which they were created. In this way, an investigation of the different shapes of Shaft may provide insight into the ways in which popular culture more broadly both mirrors and articulates specific ways of understanding society and the present.

The aim of the article is to examine how the character of Shaft appears in three movies, from three different decades (1971, 2000 and 2019), in the narrative displayed in each movie. The analysis specifically draws attention to how the character of Shaft is positioned as a subject in the movies, in relation to place, the urban territory, and other main subjects appearing in each movie, not least in the form of the African American community and its specific living conditions. On the basis of this analysis, we wish to discuss the different positions or shapes of Shaft, as displayed in the movies, as a relevant point of departure for understanding broader socio-political changes in the present.

The article is structured in the following way: First, Shaft and the three movies are put into a wider popular-cultural and political context-the early 1970s, the turn of the millennium, and current times, the late 2010s US. Second, the theoretical approach guiding the analysis of the movies is presented, as well as the way of conducting the analysis. After that, the results of the analysis are presented individually and chronologically for each movie. The analysis shows how Shaft appears in different shapes in the three movies examined. Each of these shapes may be considered a manifestation of different specific historical contexts. Finally, the main conclusions in the article are discussed in relation to what we can learn from Shaft, as a symbol of popular culture, about politics and so- 
ciety, yesterday and as well as today.

\section{Shaft in Time and Space}

The three movies examined in this article, Shaft (1971), Shaft (2000) and Shaft (2019), were produced in different times, by different directors, and partly with different crews. When examined, the movies show both similarities and differences. Common for all movies is Shaft himself, in the role of law enforcer, taking on different threats, such as drugs and organised crime, and bringing law and order to society.

The first Shaft premiered in 1971, as the first of a series of three movies (the others being Shaft's Big Score, 1972, and Shaft in Africa, 1975). Shaft is played by Richard Roundtree in all of these three movies. The movie was part of the genre Blaxploitation, that during the early 1970'-with films like Sweet Sweetback's Baadasssss, Superfly and Blacula-mainly targeted an African American audience. In these films, classical role castings were reversed, with African Americans as the main characters, and with white actors most often relegated to roles previously played by African American actors, such as crooks, perpetrators and stupid side characters (Lawrence, 2012). In many cases, these movies had uniquely recorded soundtracks, by major African American artists such as James Brown and Curtis Mayfield, contributing to a typical style, often with a political undertone. In the case of Shaft, the soundtrack was produced by Isaac Hayes. In the genre, there was strong emphasis on "hood life", where certain localities were ascribed a major significance: "blaxploitation cinema played a critical role in introducing controversial illustrations of urban life to widespread audiences and set the stage for a new era of black representation in popular culture" (Engels, 2014: p. 76). Shaft, like the blaxploitation genre in all, was part of a wider socio-political context, strongly characterized by poverty and visible polarization, for example manifested in violent protests and confrontations in US cities. A strong collective mobilization followed in the tracks of the political climate of the late 1960s, not least in the form of the civil rights movement, where social justice and the struggle against racism were in focus. In this context, a radicalization of culture emerged, where explicit political undertones were prominent in both popular film and music (Ryan \& Kellner, 1988; Eyerman, 1998).

A new version of Shaft was released in 2000, with Samuel L. Jackson as main character. The movie was part of a revival for blaxploitation, both in film and music, not least in the works of Quentin Tarantino. The movie was directed by John Singleton, who had previously directed movies such as Boyz $n$ the Hood and Higher Learning, with a strong focus on criminality, drug trafficking and gang violence, taking place in disintegrating US inner cities. Together with Spike Lee (Do the Right Thing, Jungle Fever, Clockers, Tales from the Hood), Singleton was a major influence for the wave of "new black realism" movies during the early 1990s (Bausch, 2013). As in blaxploitation, music played a central role in these movies, mainly in the form of hip-hop. Shaft 2000 unfolds in a completely 
different context than the first movie, i.e. in a NYC that Smith (1996) characterizes as a "revanchist city". NYC of the late 1990s, where the movie unfolds, was marked by a neoliberal revanchism against what was considered politically correct, against minorities as well as a general quest for social justice. As Sudjic (2016: p. 172) notes: "In a gentrified city, the poor are still segregated, but they have been pushed out of the areas in which they once lived into deprived suburbs, while the affluent have returned to colonize the centre". In this context, a "post-civil rights ideology", referred to by Bonilla-Silva (2001) as 'color-blind racism' has come to the fore, maintaining rather than challenging white privilege in US society. In the name of individual freedom and responsibility, such ideology pays no attention to the processes creating unequal living conditions for minorities, compared to the privileged (whites). In line with such ideas, referring to Henry (2004: p. 126), the movie "stunts the development of a black political voice and is complicit in charting a shift in the black community away from collective political struggle and towards individualist, self-indulgent activities...”

The most recent version of Shaft was released in 2019, once more with Samuel L. Jackson as main character. This time the movie was directed by Tim Story, who previously had directed SF movies such as Fantastic Four and comedies such as Barbershop and Think Like a Man. Compared to the previous movies, this version of Shaft has a more prominent comical element. The movie is produced in an era characterized by political polarization, also expressed in popular culture, not least movies (Izzo, 2015). This polarization is illustrated, on the one hand, by the market-oriented policies promoted by the Trump administration, with strong authoritarian elements, straightforward racism against minorities, producing as well as legitimizing inequalities (Giroux, 2017) and, on the other hand, by strong opposition against such political agenda. Such opposition is expressed in popular culture, in a range of acclaimed movies addressing explicitly political critique, not least concerning racism, like Black Panther and BlackKklansman. A corresponding polarization is further illustrated in the emergence of a "popular feminism", not least in the wake of Metoo, in parallel with an increasingly accepted popular misogyny following President Trump's verbal attacks on women and feminism (Banet-Weiser, 2018), which "presents a great challenge for the full range of women's rights globally” (Girard, 2017: p. 13).

\section{Analytical Framework}

The article departs from an analytical approach to popular culture as a barometer of the present. This means that, by analysing popular culture, we may learn about society. Popular culture illustrates current norms and ideals as well as ongoing transformations in politics and society (Bennett \& Woollacott, 1987). Through popular culture, norms and ideals are established and normalized, spread and communicated. Referring to Kellner (1995: p. 1) "media culture helps shape the prevalent view of the world and its deepest values: it defines what is good or bad, positive or negative, moral or evil". Popular culture may contribute to legitimize 
and reproduce current power relations in society, but there is also in popular culture a potential to challenge such relations, for example by articulating alternative ways of understanding the world. Thus, popular culture has "its own power to create social change-to alter social conditions and the very foundation of people's lives" (Dolby, 2003: p. 258).

Further, in line with such an argument, it has been suggested that there is a political dimension in popular culture, either implicit or explicit (Street, Inthorn, \& Scott, 2013). This political dimension is not least visible if we turn attention to popular movies, as a specific form of cultural expression (Bennett \& Woollacott, 1987; Ryan \& Kellner, 1988), for instance in terms of the ways in which racial minorities have been represented on the screen (cf. Rogin, 1996; Watkins, 1998; Lawrence, 2012). Thus, referring to Hall (1997b: p. 259), we may approach popular culture as a site where there is a constant politics of representation carried out, a struggle "to represent someone or something in a certain way". Among other popular cultural expressions, popular music has been described as a potential site for political struggle. For instance, Kasinitz and Martiniello (2019) have argued: "At the political level, popular music can be the basis for forming collective identities and can play an important role in social and political mobilization".

At the same time, it has been noted that there is a pedagogic dimension in popular culture, as people by making use of popular culture learn how to be part of society, according to current norms; what a person should look like, think and act in order to live up to current ideals (Dolby, 2003). As formulated by Dittmer (2005: p. 626): "Popular culture is one of the ways in which people come to understand their position both within a large collective identity and within an even broader geopolitical narrative or script".

As part of this ongoing struggle over meaning, subjects come into being, by being positioned in discourse. In this article, analytical focus is specifically drawn to the subject position of Shaft in the three movies investigated. Subject position here refers to the specific position that a subject takes in discourse (cf. Hall, 1997a). A subject position does not have any inherent or pre-given meaning or value. Instead, each subject position is discursively constructed, ascribed meaning and value in specific contexts. "Subject positions are relational categories that obtain their situational meaning in relation to other possible subject positions and discourses" (Törrönen, 2001: p. 216). Subjects are thus positioned in relation to other subjects, located both in time and space. The analysis presented in this article focuses on how the main character or subject of Shaft is positioned in relation to other main subjects in each movie, not least in the form of the African American community located in the urban territory where each movie takes place, and the specific living conditions of the members of this community.

The analysis has been carried out according to the following procedure: Initially, a comprehensive investigation of all three movies was carried out. This investigation was carried out by watching all movies in one sequence. This reading provided us with a coherent understanding of each movie individually as well as 
all three movies taken together, their dramaturgy and main storyline. In this stage of analysis, notes were taken concerning key scenes, events, actors and main narratives. These notes were then further analysed based on the approach to popular culture as a barometer of the present, as presented. On the basis of this analysis of the material in its entirety, a selection of a number of key scenes was made, which were then examined in more detail and transcribed verbatim. In the next stage of the analysis, an in-depth analysis of these selected scenes was made, which provides characteristic features for each movie, in terms of how the subject of Shaft is positioned in relation to other main subjects in each movie, and specifically the African American community located in the urban territory.

\section{Three Shades of Shaft}

In the following, the analysis of the three movies is presented in chronological order, starting with the first movie, Shaft (1971).

\section{Shaft in 1971}

In the first movie, the character Shaft is introduced to the viewer in a long sequence of sweeping clips, where the main character walks on the streets of NYC. First in silence, with an urban soundscape of car sounds and sirens. But thereafter the full main theme accompanies the initial sequence, quickly establishing Shaft in the role of champion for the black cause, not least in the couplet: "Who is the man who risks his neck for his brother, man? Shaft". Already in the initial sequence, the urban environment, its geography and communities, is given great significance. The cityscape is not only a backdrop for the narrative of the movie, but rather it has its life of its own. The viewer may follow Shaft moving through the city, meeting people that he passes on his way.

The story mainly takes place in Harlem, which is also the scene for violent conflicts and a power struggle engaging different criminal gangs. Shaft is a private eye, and is pulled into these conflicts as he is contacted by the African American criminal boss Bompy Jonas, who needs help to find his kidnapped daughter.

The viewer can tell that Shaft is no longer living in Harlem, but in an apartment in Greenwich Village, tastefully decorated with elegant furniture and art. Shaft has left the hood and made a career. However, Shaft still stands as a man with close relations to Harlem and its black community. In his search for the kidnapped daughter, the viewer may follow Shaft moving in the surroundings in Harlem, respectfully greeting the people he meets, in his quest for information. Shaft is presented as closely tied to the community of Harlem, even though he no longer lives in this part of the city. He appears well-informed about the territory and well-known among the inhabitants.

Like in other movies in the blaxploitation genre, music plays a crucial part of the storytelling in the movie, not least when it comes to how the urban setting is represented. In a longer sequence, accompanied by the tones and lyrics of the 
Hayes' song Soulville, the living conditions in Harlem, the urban space where the action plays out, is portrayed accordingly:

Black man, born free

At least that's the way it's supposed to be

Chains that bind him are hard to see

Unless you take this walk with me

Place where he lives got plenty of names

Slums, ghetto and black belt, they are one and the same

And I call it Soulville

Any kind of job is hard to find

That means an increase in the welfare line

Crime rate is rising too

If you are hungry, what would you do?

This is the urban space where most part of the plot unfolds. The plot deals with criminality, drug trafficking and kidnapping, but not least with a social landscape strongly shaped by inequality, poverty and racism. Shaft makes his moves in a cityscape displaying a striking gap between, on the one side, the promise of individual freedom for all, and, on the other side, the unequal living conditions that the African American population is forced to live under. This gap is also explicitly highlighted in the lyrics of the song Soulville above. While the promise tells: "Black man, born free", the realities pose the question: "If you are hungry, what would you do?"

Racial inequalities, with dramatically different living conditions for people positioned as "blacks" and "whites", is a continuous topic throughout the movie. This topic is brought forth in a range of brief sequences, for instance as when Shaft speaks on the phone and answers the question: "Do you have problems" with a quick, "Yeah, I got two: I was born black, and I was born poor". The harsh realities caused by racial inequality also clearly stands out in a sequence where Shaft waives for a taxi. The taxi stops, but leaves Shaft standing on the sidewalk. Instead, it picks up another customer further up the street. An angry Shaft shakes his fist and mutters: "You white mother..." In all, scenes such as these contribute to setting a socio-political scene where the narrative of the movie plays out. In relation to the inequalities that Shaft and the other parts of the African American population face, he acts like a champion for the African American community and its movement, claiming its rights, as an African American solidarity hero. Initially, suspicions were directed against an African American militia in Harlem, that could be interpreted as resembling a local chapter of the Black Panthers, one of the social movements at the time, that were addressing questions concerning racial inequality and struggling for black power and equal rights. The militia is led by Shaft's old friend Ben. However, in a sequence where Shaft gets hold of the militia, Ben explains that the militia has nothing to do with the kidnapping. The conversation hints that Shaft and Ben have previously gone through some tough situations together, but that they have parted company and 
chosen different paths of life. Later on, Shaft and the militia are attacked by masked men and escape, while some members of the militia are killed. Shaft explicates his scepticism towards the military tactics used of the militia: "When you lead that revolution, whitey better be standing still". Ben, in turn, accuses Shaft of having sold out to the system: "You think like a white man". Shaft answers back: "And you don't think at all".

Later on, it is revealed that the Italian-American Mafia is responsible for the kidnapping. With this information, Shaft allies himself with the African American militia in making a joint effort in order to free the kidnapped girl. The African American criminal boss Bompy Jonas is in open conflict with the white establishment, represented by the police force, as is the African American militia. However, in the movie, none of them are the real villains. Rather, the villains are represented by the white Italian-American gangsters and a faceless white privilege.

As a character, Shaft is clearly shaped in relation to place, as part of a wider African American community. Story-wise, racial conflicts are constantly present. The drawing of boundaries between the categories of black(s) and white(s) is a continuous part of the narrative, appearing in a number of different sequences in the movie. The Italian-American mafia characters are repeatedly portrayed as caricatures, particularly in the following sequence, where Shaft for the first time meets one of them, a long man dressed in suit and hat.

Mafia character: I'm looking for a nigger named John Shaft.

Shaft: You've found him, wop. Sit down.

Mafia character: I was just to take you to a lady, come on.

Shaft: I haven't finished my espresso. Why don't you have some? Maybe they'll put a little garlic in it. If you are nice.

Mafia character: No thanks. But you go ahead. You can get time to have your soul food.

Here, distinctions between Italian-Americans and African Americans are made by the usage of explicit markers, with degrading words such as nigger and wop respectively, and stereotypical associations to food, such as garlic and soul food.

An important part of the narrative in the movie is the relations between Shaft and the police, which is primarily illustrated by the Italian American lieutenant Androzzi. In several sequences, Androzzi tries to get Shaft to provide him information on what is going on in Harlem. Shaft repeatedly refuses, as he does not want to collaborate with the police. Androzzi is portrayed as part of the (white) system in the movie, but the relation between Shaft and Androzzi is not confrontational, but rather quite straight and honest. This is not least illustrated in the scene where they meet for the very first time in the movie, where the following conversation is played out:

Shaft: Warms my black heart you're so concerned about us minority folks.

Androzzi: What is it with this black shit? You ain't so black (holds a black 
pencil in front of Shaft's face).

Shaft: And you ain't so white, baby (holds a white coffee cup in front of Androzzi's face).

Androzzi: You want to play your super heavy black number?

In this scene, it is obvious the two have met before and share a common jargon. The tone is straight and ironic, but respectful. Shaft respects Androzzi, even though he is part of the system. And vice versa. The same respectful tone is noticeable also in another sequence, where Shaft and Androzzi speak about the escalating conflicts in Harlem. Here, Androzzi makes a distinction between the spatially inside view of the conflict, and the view from the outside: "It's hood against hood on the inside, but on the outside, it's blacks against whites". From this perspective, there may be several dimensions to the conflicts taking place, and thus the conflicts may appear different, depending on whether you are on the inside or on the outside. To this line of argument, Shaft responds: "You are a very wise Caucasian, Vic".

The movie ends with a grand finale in the form of a violent battle, where Shaft has joined forces with an armed African American militia. Together, they storm the hotel where the kidnapped girl is held hostage. The battle ends with the girl being freed and the militia dispersing, before the police arrive at the scene. To the sound of Hayes' main theme, Shaft finally calls Androzzi on a public phone to inform that the case is over and that it is now left to the police to clean up the mess. After finishing his call, Shaft disappears from the scene and into the darkness, walking on the street. Thus, Shaft is leaving the movie as he appeared in the beginning, walking alone, as a man of the streets, one with the city.

In summary: in this movie, the main character is strongly positioned in the urban landscape, as part of specific localities and communities, and more specifically in the deprived area of Harlem and its African American community. This urban landscape is further portrayed as characterized by racial inequalities, forming the lives of the African American community. In relation to this urban setting, Shaft appears as struggling against inequalities and bringing justice to the city. However, as portrayed in the movie, this struggle is not an individual but a collective enterprise, involving the African American militia of Harlem. As illustrated in the following, this version of Shaft in several respects differs from the versions presented in the movies from 2000 and 2019 respectively. So, let us now turn to the next version of Shaft, appearing on screen at the turn of the millennium.

\section{Shaft in 2000}

In the movie from the year 2000, the main character appears in a much more upgraded urban landscape than in the first movie. If Shaft in the first movie was clearly positioned in relation to place, and specifically a declined urban inner-city environment, the movie of 2000 is unfolding in a much more anonymised and gentrified inner-city environment. Overall, there are fewer pro- 
nounced spatial markers in the movie. No clear relation to place seems to appear, neither to specific characters. Shaft is portrayed largely as an isolated individual, with no relations to either family or a wider community, except for his uncle.

Already in the initial sequence of the movie, it is made clear that Shaft, in contrast to the first movie, is no private eye, but enrolled in the police force. Shaft enters a crime scene, where an African American man has been brutally attacked. He enters a restaurant, and approaches a young white man, Walter Wade Jr. In the first dialogue, Wade Jr has, literally, blood on his hands, which Shaft notices. Wade Jr first tries to act unknowingly about the blood, but then admits that he hit the victim in self-defence. With no regret, he summarizes the causes of events as follows: "It was like... he started it. And I finished it". Thus, Wade Jr appears as a cold-blooded murderer - and also a quite influential one, as illustrated in the dialogue that follows.

Walter Wade Jr: D'you know who my father is?

Shaft: No, do you? Take him out.

The dialogue continues outside.

Shaft: Walter Wade Junior. Big Walter Wade's son?

Walter Wade Jr: Yes, I am.

Shaft: The real estate developer.

Walter Wade Jr: Correct.

Shaft: Daddy's a big man, huh?

Walter Wade Jr: Big man. Ha. Big Man.

Wade Jr is apparently socio-economically privileged, and also well aware of this fact, as he clearly supposes that he stands above the law. At the crime scene, as the victim experiences death-throes, Wade Jr turns to Shaft, coldly stating: "Home boy's got rhythm, huh". In response to this overtly racist statement, Shaft violates the law by hitting the perpetrator and breaks his nose. A white police colleague appears and maliciously says that he has waited a long time for Shaft to lose his job. Shaft's answer is to punch Wade once more, and ask: "For that?" Shaft then leaves the crime scene, walking in the middle of traffic, to the sound of the main theme from the first Shaft movie. Just like the original Shaft character, he leaves the scene as a man who takes the law in his own hands. However, even though Shaft in this scene challenges the system, and later in the movie also leaves the system, he is still a part of it. With or without a badge, throughout the movie, Shaft has a strong confidence in the juridical system, the law and the courts, and its ability to administer justice.

In this movie, racism is portrayed mainly in individualistic terms, which means that more structural dimensions of racism become less visible than in the first movie. Throughout the movie, Wade Jr is portrayed as a symbol of racismin the form of a racist psychopath, first making racist remarks to an unknown African American man, later on totally unprovoked brutally hitting the same man with an iron bar and then showing no signs of regret-rather the contrary. 
An individualised notion of racism is also evident in the way the police are portrayed in the movie. In the following scene, Shaft takes a stand against racist jargon in the police force:

Shaft: What's with the cornbread?

Police: You got a problem with that?

Shaft: Nazis with badges, that's my problem.

Police: Nazis? I see your point. Maybe I should take an ethnic sensitivity workshop, huh? Fuck you.

Shaft: Maybe I should workshop my foot up your ass.

Here Shaft's colleague appears overtly racist and the relationship between the colleagues seems quite loaded. However, in a scene later on, Wade Jr is robbed by two masked men, stealing all the money that was about to be paid for a planned murder of an eyewitness. When the masked men later take off their masks, they are revealed as Shaft and the same white colleague as in the previous scene. They now seem to share a common jargon, raw but friendly.

Police: How did I sound?

Shaft: How did you sound?

Police: Freeze mo-fo, 'fore I bust a cap in your dome.

Shaft: Pure Notorious P.I.G.

Policeman: That means a lot coming from you.

Shaft: How much did we get?

Police: Hang on, hang on. You are so damn controlling. 42,000. That's a lot of count for a simple murder down here.

Shaft: I know cats that'd take out a whole zip code for that kind of cheese.

Police: Anyway, it's a one-time favour. OK?

Shaft: I owe you one. You are still my fucking cracker. You know that, right?

Police: Fuck you too, cornbread.

Thus, the relation between Shaft and his white colleague does not at all appear to be characterized by antipathy. The previous racist dialogue now appears as part of a raw, but friendly, jargon. Thus, there seems to be no structural dimension of racism in this version of Shaft, neither in society nor in the police force.

Despite the murder charges, Wade Jr is set free on bail. It was Shaft's violation of the law, by hitting Wade, that was the reason for justice not being served. The moral is that you shall not violate the rules of the system, as this will have consequences. Two years later, Shaft succeeds in arresting Wade Jr again and a new trial is set up. Once more, Shaft's belief in the system is put to a test. In a sequence played out in the courtroom, Wade Jr is ordered to hand in his passport, as he has already once broken his bail and fled the country. However, as clearly illustrated in the following judgement, the judge shows reverence for the social position of the accused: "I believe that young Mr Wade is sincere in his desire to deal with whatever form of judgement this room deems necessary to deliver. Bail 
is set at one million dollars".

Once more, Wade Jr is set free, awaiting his trial. Admittedly, against higher bail than last time, but for Wade this is just a small sum of money. The lawyer immediately informs that bail will be paid. The camera zooms in on both the privileged father of Wade Jr, satisfied with the verdict, and the mother of the victim, crying of the injustice unfolding. The scene ends with Shaft demonstrating his frustration by throwing his police badge and thus leaving the police force. During the rest of the movie, he continues serving justice, outside the police force. However, he continues to be seen as still part of the force, and also acts like he still is, for example by using the social capital and favours he has established as a policeman. Thus, in contrast to the first movie, Shaft remains a guardian of the law, with or without badge.

In the very last sequence of the film, Wade Jr is again set to face justice in court. Outside of the courthouse, Shaft has the following dialogue with the mother of the victim.

Shaft: This morning we have a whole new line-up. We got a new judge. The DA himself is running the prosecution. And we have an eyewitness. Today, we're gonna get our money's worth.

The mother: I know we will.

Once more, Shaft appears as a preserver of the law, still with a strong belief in the legal system. There may be corrupt judges, as well as racist police officers, but these are individuals. The system at large still works. However, in the final sequence of the movie, the mother of the victim loses her faith in the system and its ability to serve justice. Instead, she takes the law into her own hands, shoots and eventually kills Wade outside the courthouse. As the system cannot guarantee that justice will be served, she decides to serve justice in her own way. As a representative of the system (the police force), Shaft is not able to stop Wade with violence. However, after the killing of Wade Jr, he smiles, almost approvingly, towards the mother. She stands still, stoically, and is put in handcuffs by uniformed police, with a chorus of voices chanting: "Let her go".

In the movie, Shaft is portrayed as a witness to inequalities in NYC at the turn of the millennium, illustrated by the character of Wade Jr. As a privileged, white upper-class male, he seems to be able to do whatever he wants and almost gets away with it. In contrast to the first movie, Shaft does not take a political stand to these inequalities, by acting outside the system. Instead, he continues to act within the system, guided by his hope that the system will eventually serve justice. Thus, in Shaft 2000, the struggle against injustice has changed its focus, from the streets to the courtroom. Injustice as well as responses to it are portrayed in individual terms. There is no trace of collective action, neither in terms of causing, nor in terms of responding to injustice. Even though people are obviously not treated as equals before the law, the belief in the system prevails.

The film ends with Shaft handing in his badge and weapon, leaving the police force. In the very last sequence, played out during the end notes and to the 
sound of Hayes' main theme, Shaft disappears, driving away in a car together with his uncle, to start a new life as a private eye. Thus, in contrast to the first movie, it is not a lone Shaft that leaves. In this way, the movie opens up for the focus of the next version of Shaft, with the family in the centre of attention.

\section{Shaft in 2019}

In the most current version of Shaft, from 2019, the character is mainly portrayed in relation to his family and its different generations, rather than in relation to place or a wider community. Like in Shaft 2000, urban space is mainly an anonymous backdrop for the narrative in the movie. The spatial environment glimpses through in short sequences, during chases and in panoramas of Manhattan's iconic skyline, but as represented, Shaft has no relation to the place. The main narrative in the movie is rather concentrated to the relations between Shaft and his relatives.

The movie starts with a sweeping camera shot over a Manhattan in darkness, a famous skyline, but without the same closeness and emphasis as in the first movie. The introduction takes us back to Harlem 1989 and a scene where Shaft is in a car with his girlfriend Maya, and their son, JJ (John Shaft Jr). They are suddenly shot at by men sent out by the gangster Gordito. To the sound of Hayes' Theme from Shaft, gunfire breaks out and the scene ends with Maya once and for all leaving Shaft to save her son from such violence. In a following sequence of flashbacks, the viewer then follows Maya, JJ and Shaft over the years, through 1994, 1997, 2001, 2007, 2009 and 2012, to a "present day", in a series of clips with things happening, including gifts from Shaft to his son.

The relation between Shaft and the gangster Gordito, who was the main reason for the family breakdown, is part of the metanarrative of the movie. As made explicit early on in the movie, Shaft still has not let the case go, three decades after the first sequence took place. During all this time, Shaft has continued hunting Gordito. However, the narrative is primarily built around the relation between father and son, as the movie illustrates how they make contact again, after a long period with no contact at all. During the film, the viewer can follow how the relationship between father and son develops.

It is revealed early on that JJ is working for the FBI, while Shaft, like in the first movie, works as a private eye. After JJ's friend Karim is found dead, JJ decides to contact his father to ask for help in solving the case. Throughout the film, Shaft is portrayed as an outdated relic. It is as if he has not been changed by time. Shaft is still working in his old office, with the same door as in the first movie, carrying values that are clearly outdated. Not least his views on the relationships between men and women. In relation to his father, the son is portrayed as a man of the current times, its values and spirit. The reunion of father and son is illustrated as an encounter of generations and times, as opposites. When Shaft notes an FBI badge under JJ's jacket, the following dialogue unfolds:

Shaft: Oh-oh, so my blood is collecting checks from the FBI? 
JJ: That's right.

Shaft: How does it feel, working for the Man?

JJ: You mean having an actual job? Like, paying taxes? Not living off the grid in an all-cash sublet? It's great.

Shaft: So, you live in the city now? No, don't tell me. Down in Soho, exposed brick loft, with a bi-curious roommate and a little furious dog, and a farmhouse sink?

JJ: Have you been stalking my Facebook?

Shaft: Do I look like I'm on Facebook, motherfucker? You're coming here with your skinny-ass jeans, your button-up Gap shirt and what looks like some badmin-fucking Nikes. Haha. Any nigger with two eyes and a dick can read you a mile away. Oh, my, your mum did a hell of a job turning you into a bona fide white boy.

In the first movie, Shaft had made a social climb, from the ghetto to the finer parts of town. In this movie, it is the son that has made a corresponding climb. In a scene later in the movie, the viewer gets to see JJ's apartment, which is somewhat reminiscent of the apartment that Shaft housed in the first movie, as Shaft helps his son home after a late club night together.

The contrast between father and son is clearly illustrated as Shaft is portrayed as an outdated macho-figure with a lower social rank than JJ. Where and how Shaft himself lives is not revealed in the movie, but judging by this scene, father and son live very different lives, under very different conditions, in very different housings. Despite these contrasts, and quite a harsh beginning on resuming contact between father and son, Shaft and JJ slowly learn to know each other. Shaft teaches JJ not to be so subtle and defensive in his relations to women. The relation between father and son is about to change. From different directions they meet, and learn from each other. This is followed by a scene where Shaft is learning his son more about life - especially about the relationships to women and there is a negotiation played out concerning how a man should behave. Here, different epochs are presented as opposites:

JJ: I'm pretty sure women don't like being told what it is that they like...

Shaft: You see, that is the shit that I'm talking about. Men used to be men. Now, you millennium motherfuckers run around worrying about what women think and how they feel and apologizing and shit. That's embarrassing. JJ: Apologising is embarrassing?

Shaft: Yes, men don't apologise. That's a trap they set for us. Real men just own their shit.

JJ: No, real men take responsibility for what they do. Real men are strong enough to admit when they are wrong.

Shaft: Real men are strong enough to put their foot in motherfuckers' ass when they are pissed off.

JJ: Is that the Shaft family motto? 
Shaft: That's an unwritten law.

Here, Shaft represents another time and another way to think and to be, as compared to his son, who appears as a representative of the current times, its values and ideals. According to Shaft's views, it was better in previous times, when men were real men. JJ, in turn, maintains that real men take responsibility and admit their shortcomings, clearly making a point to his father, who has stayed away all these years and not resumed contact with his son. During the movie, Shaft is resuming relations to both his son and Maya, and undergoes a transformation. The turning point is a scene where Shaft, after a violent shoot-out, where he, JJ and Maya all participate, apologizes to Maya for exposing his family to danger. In this scene, Shaft demonstrates that he has also, indeed, learnt from his son, and is on the verge of transforming - to become part of the current times.

Before the grand finale of the movie, father and son make a visit to grandfather Shaft, here portrayed by Richard Roundtree, to take part of his armoury. In this scene, it is also revealed that grandfather earlier had pretended to be Shaft's uncle (in Shaft 2000, the uncle was also played by Richard Roundtree, who was also the main character in the movies of the 1970s). There is notable friction between Shaft and his father, even though they have kept contact during the years. In the scene, grandfather and JJ are getting acquainted, to music reminiscent of Hayes' soundtrack from the first Shaft movie. And in joint forces, three generations of Shaft set out for the settlement with Shaft's nemesis, Gordito. In this settlement, Shaft is injured and brought to hospital. There, the family gathers, son, grandfather, Maya and Sasha. At the request of the two older Shafts, JJ now kisses Sasha and in the following scene, JJ returns to the FBI office and gets welcomed like a hero. Cheered on by his peers, he is told by his boss that he is welcome back on duty. But instead of happily receiving the announcement, JJ answers: "I'm not coming back. I'm done working for the man". The main theme starts playing as JJ continues: “And the name is Shaft. John Shaft". Outside the bureau, the similarly dressed Shaft and grandfather are waiting. They have started up a family private eye firm, and all three generations Shaft approaches the camera on their way to their first mission, not to save the world, but a petty insurance crime.

This last scene makes a symbolic appeal for the nuclear family, in line with the overall narrative of the movie, with a strong focus on intergenerational meetings and reunion. Consequently, in this movie, Shaft is not engaged in a struggle against injustice in society, but rather against a modern form of masculinity, where men are no longer allowed to be men. Contrary to the previous movies, racism is strikingly absent. The only glimpses of racism are found in a short sequence where JJ accuses a journalist-that in a news story addresses the suspicions towards the police force for islamophobia-as a case of racism in reverse. Otherwise, there are no signs of injustices in the movie, based on neither race nor class. This may be a strategic choice by the producers, as the merited direc- 
tor of Shaft (2019), in contrast to the directors of the previous movies, clearly lacks a proven track-record as director of socio-political commentary. However, the lack of critical remarks on issues of racial inequalities makes Shaft (2019) feel strikingly outdated already in 2020, in an American society strongly marked not only by the crisis of Covid-19, but also by the wide-ranging popular outcries against racism following Black Lives Matter.

The dimension of class is also present only in the form of African American upward social mobility, where JJ in a way comes to embody the "American dream", while Shaft appears as a historic relic, left in the time and place where he was seen in the first movie. However, in the last scene, Shaft finds his way back home, to the nuclear family, and to the right time. In line with the "American dream", the moral of the movie is that African Americans can succeed, if the family is united and its members support each other, over generations.

\section{Findings and Conclusion}

This article departs from an approach to popular culture as a barometer of the ideals and political trends of the times. In line with this approach, we have directed our attention to the African American action movie hero Shaft, and how this character is positioned in different ways, in three movies from different times. On the basis of the analysis conducted, we would here like to summarize some of our main findings and discuss the different positions of Shaft, as displayed in the movies, as a point of departure for understanding broader sociopolitical changes in the present.

Two of the movies unfold during quite radical times: Shaft 1971 unfolds in the aftermath of the social movements of the late 1960s. Shaft 2019, in turn, unfolds in an austere political climate with strong polarization in American society. Meanwhile, Shaft 2000 unfolds in a seemingly non-confrontational era around the turn of the millennium, a time where ideologies are told to be dead, and neoliberalism prevails.

As noted previously in this article, the first Shaft is one of the leading blaxploitation movies, a genre with a specific focus on the situation of African Americans in decayed urban inner cities. This movie is marketed and targeted for mainly an African American audience. The relationships visualised in the film are mainly mirrored through a perspective related to race, either visibly or latently. As we have illustrated, the presence of the civil rights movement, specifically in the form of a militia resembling the Black Panthers, is continuously strong, both in the dramaturgy and the dialogues in the movie. Race is displayed in the relation between African Americans and Italian Americans, while other categories of people are quite invisible.

The second version of Shaft is unfolding in a post-Reagan, post-Bush Sr and post-Clinton US, in a socio-political climate characterized by conservatism and neoliberalism. The issue of race and racism is significantly less present than in the first movie. Most notably, as highlighted in the analysis, racism is more indi- 
vidualised, with the lone, psychopathic racist as the main illustration of racism. In its place, individualism and class-based inequalities produced in a neoliberal city emerges as a prominent theme in the movie, with a specific attention paid to the judicial positive discrimination of the wealthy and privileged. In contrast to the first movie, the second version of Shaft was marketed to a mixed audience, which may provide clues of how to make sense of the way of dealing with race in the movie.

The third version of Shaft unfolds in a neo-conservative US under Trump's presidency, which is illustrated by a strong emphasis on family values and inter-generational relations, while the issues of race, individualism and class highlighted in the previous movies are now strikingly absent. The highly polarized political climate in contemporary US is not at all made present in the movie. The story unfolds in Shaft finally finding his way back to the family and its core values. Like the second version of Shaft, the third also targets a broad audience. By leaving race and class issues invisible and uncommented, Shaft 2019 also exemplifies how fast and fiercely outdated a movie may become, when failing to be a relevant barometer of the present.

Turning to the meaning of place, the three movies differ significantly. In the first version of Shaft, the narrative unfolds in well-defined mythological places in NYC (primarily in Harlem). In the latter versions, place is significantly more anonymous. The narrative is relocated, from a deprived to a gentrified and upgraded location in NYC. This also corresponds to the actual gentrification of inner-city taking place in NYC overall, and particularly in Manhattan and parts of Brooklyn. In the first movie, Harlem provides the narrative with a strong mythological dazzle, while there is no such mythological status in the latter movies. For Shaft 1971, unfolding in the civil rights era, with race at the centre of attention, the locality in itself is loaded with a strong symbolic meaning. In the latter movies, there is no apparent spatial symbolism, concerning neither class (in both movies, there are brief visual markers of south Manhattan, but these are not emphasised), nor family (in both movies, the upgraded locality where the narrative unfolds remains quite anonymous).

\section{Final Reflections}

Popular culture includes a multitude of simultaneous figures and symbols, of which Shaft is one. As illustrated in this article, the figure of Shaft changes and so does the times. As in other times, popular culture remains a battleground, where Shaft and other combatants within the realm of popular culture are engaged in the politics of representing the present, as well as the past and the future.

In the article, we have highlighted how the first version of Shaft actively portrays the political struggles carried out in the civil rights era. On the contrary, as positioned, the second version of Shaft is significantly less actively engaged in the political struggles of the day. However, the movie still reflects class-based 
injustices in an individualised neoliberal era. As positioned in the most previous movie, the third version of Shaft, in turn, neglects the social struggles of the day. By celebrating family values, by neglecting existing inequalities as well as the possibilities of collective actions targeting these inequalities, the movie makes a post-political statement, echoing a long-established myth of the "American dream", with hopes of intergenerational social mobility. In this appearance, Shaft is positioned in a way that makes collective action for equal rights appear as belonging to the past. While criticism about neglecting social struggles and racial inequalities could have been raised in 2019, the rapid politicization of the political climate in the US in the wake of the BLM protests in 2020 has left the latest incarnation of Shaft outdated, only a year after its release. The action hero Shaft of 2019 portrays NYC of today as a post-political scenery with a focus on family values while issues of racial and socio-economic inequalities as well as racism in the police force remain tellingly absent. In spring 2020, in the same NYC, and elsewhere throughout the world, street artwork and a wide range of other popular cultural expressions comment on BLM and engage in political protest against racism and police brutality. This contrast clearly illustrates how popular culture may be understood as a barometer of the present, as it rapidly can become politicized, as well as de-politicized (and re-politicized all over again).

Thus, we can learn a great deal from interrogating the different shades of Shaft appearing in movies produced in different times, each of them providing a useful basis for highlighting as well as problematizing the socio-political climate and contestations of each time. By investigating these representations of Shaft, we are not least provided with possibilities to understand and problematize the politics of the present. Shaft is a sign of the times, but also a sign of different times. Neither Shaft nor time stands still. This is one lesson to be learnt from investigating (three shades of) Shaft.

\section{Conflicts of Interest}

The authors declare no conflicts of interest regarding the publication of this paper.

\section{References}

Banet-Weiser, S. (2018). Empowered. Durham: Duke University Press. https://doi.org/10.1215/9781478002772

Bausch, K. (2013). Superflies into Superkillers: Black Masculinity in Film from Blaxploitation to New Black Realism. The Journal of Popular Culture, 46, 257-275. https://doi.org/10.1111/jpcu.12025

Bennett, T., \& Woollacott, J. (1987). Bond and Beyond. London: Palgrave. https://doi.org/10.1007/978-1-349-18610-5

Bonilla-Silva, E. (2001). White Supremacy and Racism in the Post-Civil Rights Era. Boulder, CO: Lynn Rienner.

Dahlstedt, M., \& Vesterberg, V. (2021). Politics of Makeover: Initiating Organisational Change and Positioning the Unemployed in a Swedish Reality TV Series. International 
Journal for Politics, Culture and Society. https://doi.org/10.1007/s10767-021-09399-3

Dittmer, J. (2005). Captain America's Empire: Reflections on Identity, Popular Culture, and Post-9/11 Geopolitics. Annals of the Association of American Geographers, 95, 626643. https://doi.org/10.1111/j.1467-8306.2005.00478.x

Dolby, N. (2003). Popular Culture and Democratic Practice. Harvard Educational Review, 73, 258-284. https://doi.org/10.17763/haer.73.3.1225466106204076

Dorzweiler, N. (2016). Popular Culture in (and out of) American Political Science. History of the Human Sciences, 30, 138-159. https://doi.org/10.1177\%2F0952695116684314

Engels, D. (2014). Baadassss Gangstas: The Parallel Influences, Characteristics and Criticisms of the Blaxploitation Cinema and Gangsta Rap Movements. Journal of Hip Hop Studies, 1, Article No. 7. https://doi.org/10.34718/S4J2-BP90

Eyerman, R. (1998). Music and Social Movements. Cambridge: Cambridge University Press. https://doi.org/10.1017/CBO9780511628139

Girard, F. (2017). Implications of the Trump Administration for Sexual and Reproductive Rights Globally. Reproductive Rights Matters, 25, 6-13. https://doi.org/10.1080/09688080.2017.1301028

Giroux, H. A. (2000). Public Pedagogy as Cultural Politics: Stuart Hall and the Crisis of Culture. Cultural Studies, 12, 341-360. https://doi.org/10.1080/095023800334913

Giroux, H. A. (2017). The Public in Peril. New York, NY: Routledge. https://doi.org/10.4324/9781315173238

Hall, S. (1997a). The Work of Representation. In S. Hall (Ed.), Representation (pp. 1364). Milton Keynes: Sage.

Hall, S. (1997b). The Spectacle of 'the Other'. In S. Hall (Ed.), Representation (pp. 225279). Milton Keynes: Sage.

Henry, M. (2004). He Is a "Bad Mother*\$\%@!\#”: "Shaft” and Contemporary Black Masculinity. African American Review, 38, 119-126. https://doi.org/10.2307/1512235

Izzo, D. G. (Ed.) (2015). Movies in the Age of Obama. Lanham: Rowman \& Littlefield.

Kasinitz, P., \& Martiniello, M. (2019). Music, Migration and the City. Ethnic and Racial Studies, 42, 857-864. https://doi.org/10.1080/01419870.2019.1567930

Kellner, D. (1995). Media Culture. New York, NY: Routledge.

Lawrence, N. (2012). Blaxploitation Films of the 1970s. New York, NY: Routledge.

Rogin, M. (1996). Blackface, White Noise: Jewish Immigrants in the Hollywood Melting Pot. Berkeley, CA: University of California Press.

Ryan, M., \& Kellner, D. (1988). Camera Politica. Bloomington, IN: Indiana University Press.

Shaft (1971). Gordon Parks. New York, NY: Metro-Goldwyn-Mayer. [Film]

Shaft (2000). John Singleton. New York, NY: Scott Rudin Production/New Deal Productions. [Film]

Shaft (2019). Tim Story. New York, NY: New Line Cinema/Davis Entertainment/Netflix Original Films. [Film]

Smith, N. (1996). The New Urban Frontier. Hoboken, NJ: Taylor \& Francis.

Street, J., Inthorn, S., \& Scott, M. (2013). From Entertainment to Citizenship. Manchester: Manchester University Press.

https://doi.org/10.7228/manchester/9780719085383.001.0001

Sudjic, D. (2016). The Language of Cities. London: Penguin Books.

Törrönen, J. (2001). The Concept of Subject Position in Empirical Research. Journal for 
the Theory of Social Behaviour, 31, 313-330. https://doi.org/10.1111/1468-5914.00161

Watkins, S. C. (1998). Representing: Hip Hop Culture and the Production of Black Cinema. Chicago, IL: The University of Chicago Press. 